\title{
Application of UAV for Sewer Pipe Inspection
}

\author{
Yusuke Inagaki, Hiroshi Ikeda, Yoshihiko Yato, Patrik Ken Takeuchi and Masatoshi Anakura* \\ NJS Co., Ltd., Minato-ku, Tokyo, Japan
}

\begin{abstract}
*Corresponding author: Masatoshi Anakura, NJS Co., Ltd., 1-1-1 Shibaura, Minato-ku, Tokyo 105-0023, Japan, E-mail: masatoshi_anakura@
\end{abstract} njs.co.jp

Received: 28 Jul, 2020 | Accepted: 12 Aug, 2020 | Published: 18 Aug, 2020

Citation: Inagaki Y, Ikeda H, Yato Y, Takeuchi PK, Anakura M (2020) Application of UAV for Sewer Pipe Inspection. Int J Water Wastewater Treat 6(2): dx.doi.org/10.16966/2381-5299.169

Copyright: (c) 2020 Inagaki Y, et al. This is an open-access article distributed under the terms of the Creative Commons Attribution License, which permits unrestricted use, distribution, and reproduction in any medium, provided the original author and source are credited.

\section{Abstract}

The objective of this study is to evaluate the effectiveness of utilizing a UAV (Unmanned Aerial Vehicle) in sewer pipe inspection as a method to screen pipelines and identify which require further detailed inspection. An experiment was conducted by comparing inspection speed, operator's safety, and reliability of data against conventional inspection methods, CCTV (Closed Circuit Television) and manhole camera. The result was that UAV could inspect the same pipeline length in fewer days when compared to the other methods proving to be highly efficient, and can also be considered a safe method as the operation can be completed without the operator entering a manhole throughout the inspection. The reliability of data was also sufficient as the UAV could collect images of inside the pipe with high visibility. From the obtained result, it can be said that UAV is an effective screening method to efficiently conduct CCTV inspection.

Keywords: UAV; Sewer pipe inspection; Screening; Operator safety; Maintenance

\section{Introduction}

Modernization of the sewer system in Japan started in 1965, followed by an extensive construction in the next 20 years. By the end of 2018, the sanitation coverage reached $79.3 \%$. Along with the growth of coverage rate, the total sewer length has grown at a rapid pace, reaching approximately $480,000 \mathrm{~km}$ in the recent statistics [1].

The typical service life of a sewer pipe is considered to be 50 years [2]. The latest statistics show that $17,000 \mathrm{~km}$, approximately $4 \%$ of the total existing pipes exceed this age. Every year, more than 3,000 urban road collapse cases occur due to the deterioration of aging pipes, causing a serious concern to the society. As we see the increasing number of aging pipes, we fear to see more road collapse incidents [3].

The main method today in Japan for detailed visual inspection of sewer pipes is CCTV (Closed Circuit Television). CCTV inspection can find defects within the pipe and collect close images for inspection. Data reliability is high as CCTV will stop to see each defect, however it is not the most efficient as the operator would search for any defects as the CCTV travels through the pipe. Safety is of concern, as it requires the operator to enter the manhole to insert the CCTV inside the pipe. Such environment may have low oxygen or contain hazardous gas. It can also be unsafe for the operator in cases of sudden rainfall [4].

Manhole cameras are commonly used for screening the pipeline to identify the sections which require detailed inspection. It is an efficient and safe method but has a limited line of sight not enough to photograph the entire pipe path.
Pipeline screening and prioritizing is considered to be effective in sewer pipe maintenance. An efficient and safe method to visualize the pipeline entirely can be highly effective in screening. This study focuses on utilizing a UAV (Unmanned Aerial Vehicle, commonly referred to as "drone") as an efficient, safe, and reliable way of screening pipes. Evaluation was conducted with an experiment comparing UAV against commonly used inspection methods, CCTV and manhole camera $[5,6]$.

\section{Materials and Methods}

\section{Devices}

The devices used for inspection were CCTV, manhole camera and UAV. CCTV had a resolution of 410,000 pixels, the manhole camera had 2,000,000 pixels, and the UAV, 2,000,000 pixels. The specification of the UAV can be found in table 1 and its appearance in figures 1 and 2 .

\section{Inspected section}

The pipeline section used for evaluation was as below:

- $\quad$ Pipe usage $=$ combined sewer

- Pipe diameter $=400 \mathrm{~mm}$ to $600 \mathrm{~mm}$

- $\quad$ Pipe material=concrete

- $\quad$ Number of lines (paths) $=30$

- Total length $=1,324.8 \mathrm{~m}$ 


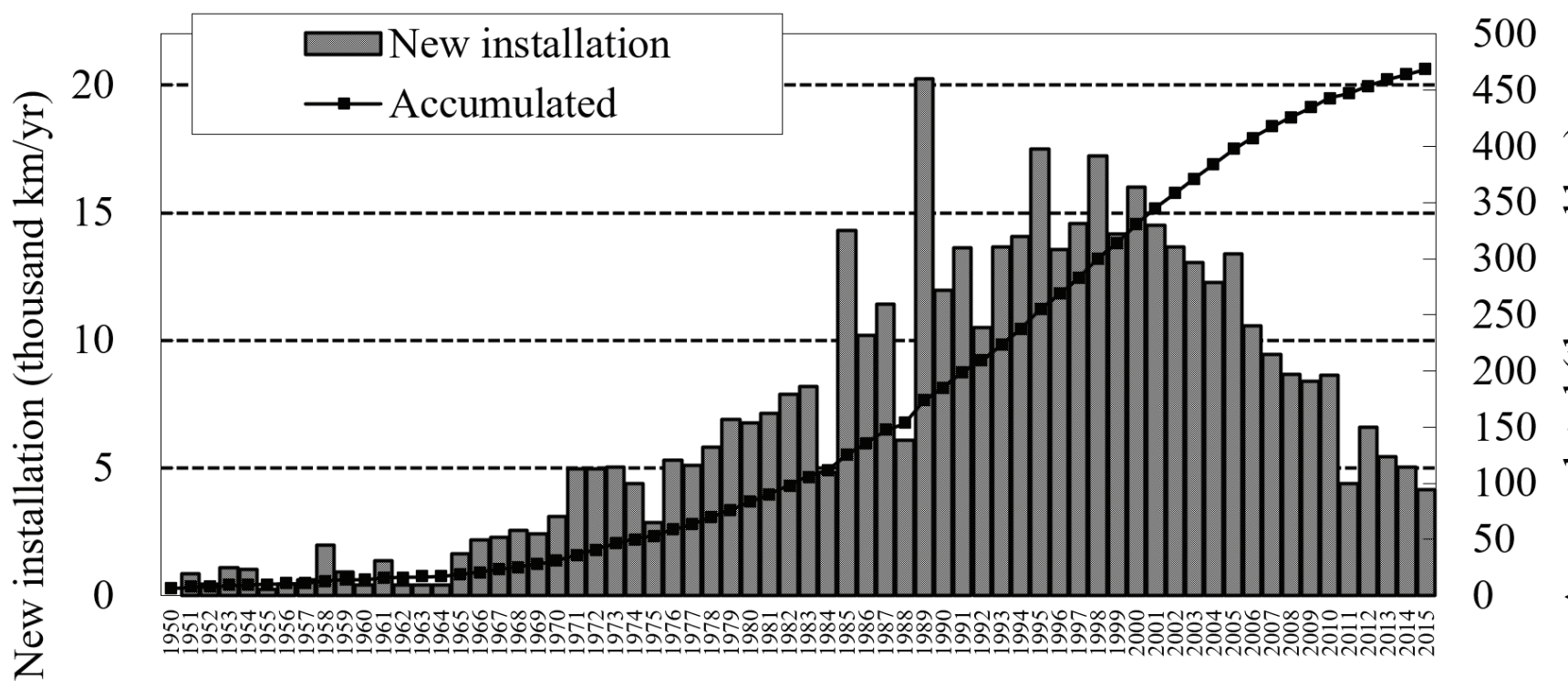

Figure 1: New sewer construction and accumulated length by year in Japan.

Made by author, based on the statistics of Japan Sewage Works Association [3].

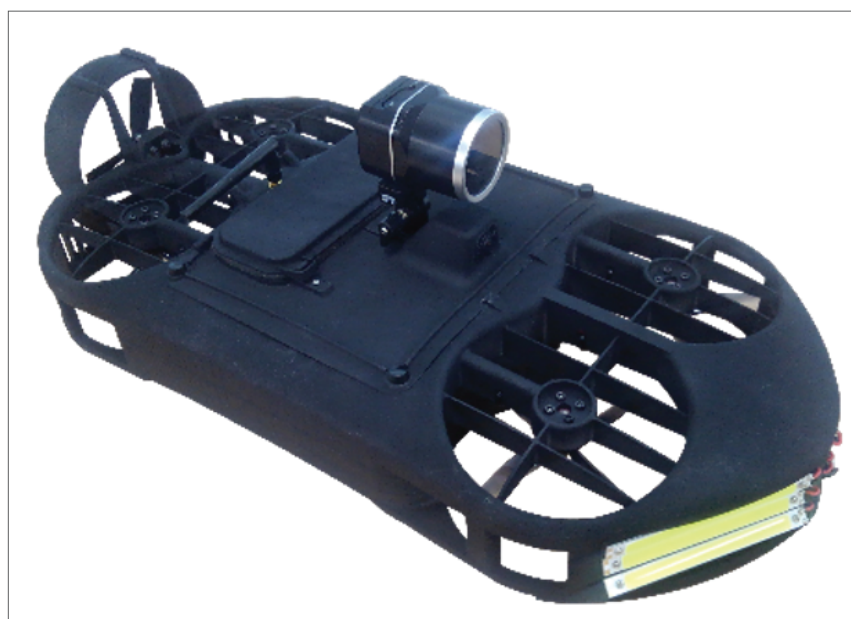

Figure 2: Appearance of the UAV.

The paths are lined up in a straight line, as can be seen in figure 3 . The pipe was cleaned before CCTV inspection but not for manhole camera or UAV.

\section{Method of evaluation}

The inspection team inspected the same section with CCTV, manhole camera and UAV. The team evaluated the efficiency/ reliability of UAV by inspection speed, operator's safety and reliability of data.

The index values of "inspection speed" were the number of days required for inspection, the number of manhole openings, the average inspection path per manhole and the average of inspected length. Efficiency can be judged high if the number of days required for inspection with UAV is fewer than existing methods.
Table 1: Specification of the UAV.

\begin{tabular}{|l|l|}
\hline \multicolumn{1}{|c|}{ Item } & \multicolumn{1}{c|}{ Specification } \\
\hline Size & W:250mm L:570mm H:190mm \\
\hline Weight & $2.0 \mathrm{~kg}$ (including battery) \\
\hline Flight duration & Approx. $5 \mathrm{~min}$ \\
\hline Flight speed & $0.5 \mathrm{~m} / \mathrm{s}$ to $3.0 \mathrm{~m} / \mathrm{s}$ \\
\hline Inspection camera & Panasonic stabilizer camera \\
\hline Resolution & Approx. $2,000,000$ pixels \\
\hline View angle & 84 deg. \\
\hline
\end{tabular}

Table 2: Comparison Index.

\begin{tabular}{|l|l|}
\hline \multicolumn{1}{|c|}{ Index } & \multicolumn{1}{c|}{ Values } \\
\hline Inspection speed & Number of inspection days \\
\hline Operator's safety & $\begin{array}{l}\text { Number of inspections without entering the manhole } \\
\text { (Inspections without entry / Manhole openings) }\end{array}$ \\
\hline Reliability of data & Matching rate of defect detection to CCTV \\
\hline
\end{tabular}

The index for "operator's safety" was set to be the number of manhole openings which operators were not required to enter. A higher number would mean the operator is less exposed to unsafeness such as low oxygen, hazardous gas, or sudden rise of water level due to unexpected rainfall.

The reliability of the data obtained by UAV was examined by the number of detected defects matched to the CCTV results, i.e., setting CCTV as a benchmark. When the detection rate is $100 \%$, the reliability can be said to be the same to CCTV. When the rate is higher compared to manhole camera, the reliability can be said to be greater than that of a manhole camera. 


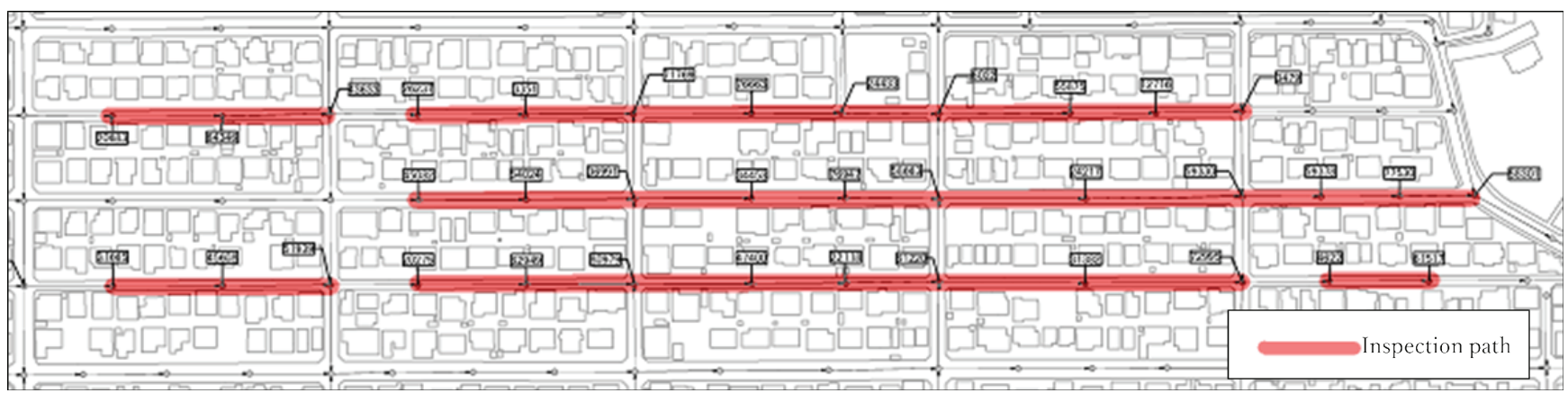

Figure 3: Inspection Path.

\section{Results and Discussion}

The comparison of the three inspection methods was evaluated by (1) inspection speed, (2) operator's safety and (3) reliability of data. Details of each evaluation are described below.

\section{Inspection speed}

The total duration time for UAV to inspect the length was 4 hours and $18 \mathrm{~min}$, including preparation, tuning of devices and clean up. Converted to an entire working day of 8 hours, a whole day inspection length would be $2,904 \mathrm{~m}$.

Tables 2 and 3 shows the number of days required to inspect the total length of $1,324.8 \mathrm{~m}$ : CCTV $=4$ days, manhole camera $=2$ days and $\mathrm{UAV}=1$ day. UAV had the least amount of days needed compared to CCTV, manhole camera. This owes to the fact that UAV required less time to set up at each manhole, can travel through the pipe faster than CCTV, and also was able to inspect one path in the upstream direction and two paths in the downstream direction, resulting in a maximum of three paths from a single opening. The UAV's average inspection time per manhole was 12 min 23 seconds.

The number of manhole openings required to inspect the whole length was, $\mathrm{CCTV}=30$ openings, manhole camera $=36$ openings and $\mathrm{UAV}=15$ openings, showing UAV to have the least number of openings of all. The average number of inspection paths per manhole was $C C T V=1.0$ path, manhole camera $=0.8$ path and $U A V=2.0$ paths. The average length of inspection per manhole was CCTV $=44.16 \mathrm{~m}$, manhole camera $=36.8 \mathrm{~m}$ and $\mathrm{UAV}=88.32 \mathrm{~m}$. The results indicate that UAV inspection is most efficient of the three methods tested, in terms of the number of days required, average number of inspection paths and inspection length per manhole $[7,8]$.

\section{Operator's safety}

Operator's safety was quantified by the number of manhole

Table 3: Comparison of the inspection methods.

\begin{tabular}{|l|c|c|c|}
\hline & CCTV & $\begin{array}{c}\text { Manhole } \\
\text { camera }\end{array}$ & UAV \\
\hline Number of days needed & 4 & 2 & 1 \\
\hline Number of manhole openings & 30 & 36 & 15 \\
\hline Average inspection path per manhole & 1.0 & 0.8 & 2.0 \\
\hline Average of inspected length per manhole & 44.16 & 36.8 & 88.32 \\
\hline
\end{tabular}
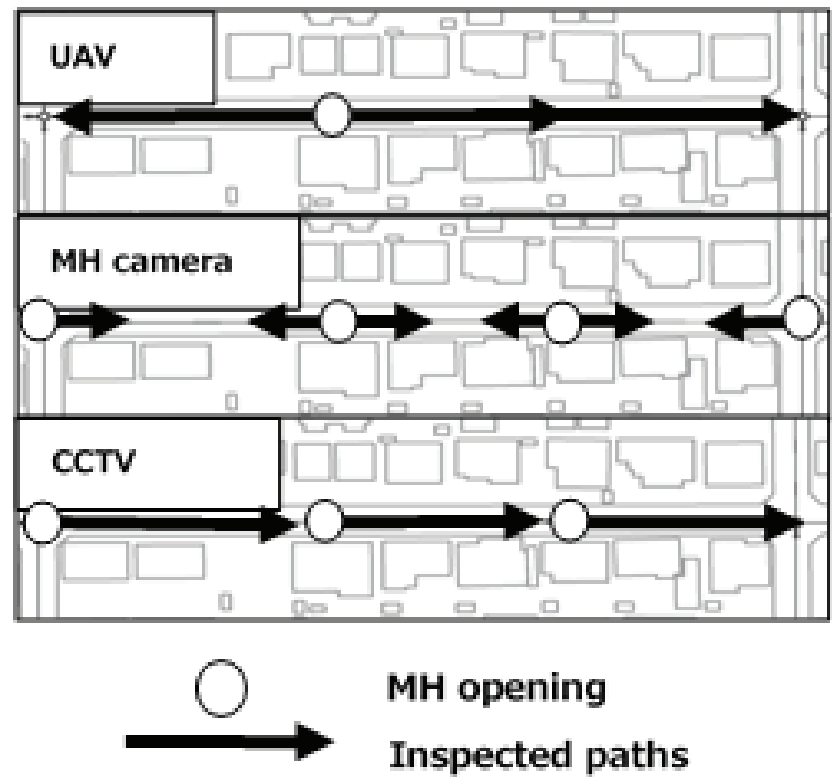

Figure 4: Manhole openings and the inspected paths.

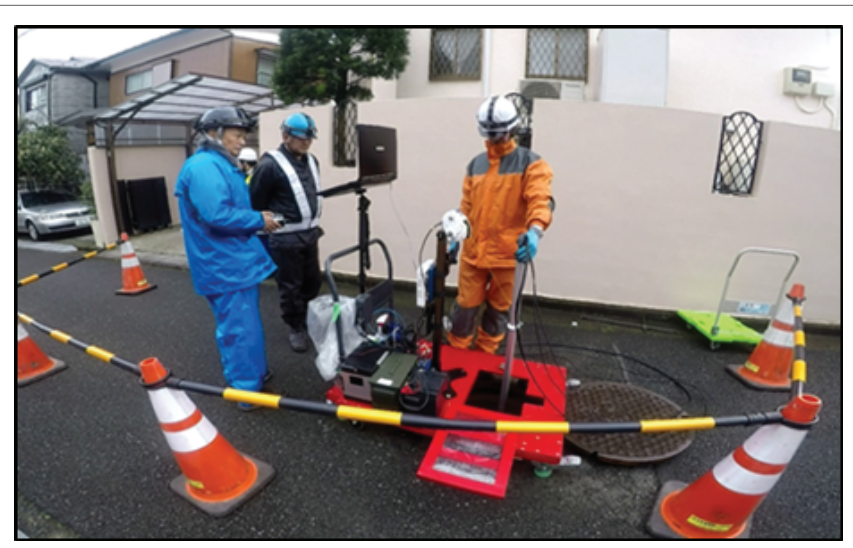

Figure 5: Operators working from above ground in UAV inspection. 
Table 4: The result of the CCTV inspection.

\begin{tabular}{|c|c|c|c|c|c|c|c|c|c|c|c|c|c|c|c|c|c|c|c|c|c|}
\hline \multicolumn{3}{|c|}{ Corrosion } & \multicolumn{3}{|c|}{$\begin{array}{l}\text { Sagging in vertical } \\
\text { direction }\end{array}$} & \multicolumn{3}{|c|}{ Breakage } & \multicolumn{3}{|c|}{ Cracks } & \multicolumn{3}{|c|}{ Displaced joints } & \multicolumn{4}{|c|}{ Infiltration } & \multicolumn{3}{|c|}{$\begin{array}{c}\text { Extrusion of lateral } \\
\text { pipes }\end{array}$} \\
\hline A & B & $\mathrm{C}$ & A & B & $\mathrm{C}$ & $\mathrm{a}$ & $b$ & c & a & $b$ & c & $\mathrm{a}$ & & c & a & & $b$ & C & $\mathrm{a}$ & $b$ & c \\
\hline 0 & 1 & 2 & 0 & 0 & 0 & 3 & 8 & 6 & 1 & 5 & 8 & 0 & & 3 & 0 & & 0 & 1 & 0 & 0 & 1 \\
\hline \multicolumn{3}{|c|}{ Root intrusion } & \multicolumn{3}{|c|}{$\begin{array}{l}\text { Attached deposit } \\
\text { (mortar) }\end{array}$} & \multicolumn{3}{|c|}{ Others } & \multicolumn{13}{|c|}{ Total } \\
\hline a & b & c & $\mathrm{a}$ & $b$ & C & $\mathrm{a}$ & $\mathrm{b}$ & C & A & B & $\mathrm{C}$ & \multicolumn{2}{|c|}{ Total } & $\mathrm{a}$ & b & c & & \multicolumn{4}{|c|}{ Total } \\
\hline 0 & 3 & 0 & 0 & 0 & 4 & 0 & 0 & 1 & 0 & 1 & 2 & \multicolumn{2}{|c|}{3} & 4 & 16 & 24 & & \multicolumn{4}{|c|}{44} \\
\hline
\end{tabular}

Explanation for each level $A(a)-C(c)$ is in table 5 .

Whole length assessment: $A=$ most severe $\rightarrow C=$ less serious

Local (pipe-wise) assessment: $a=$ most severe $\rightarrow c=$ less serious

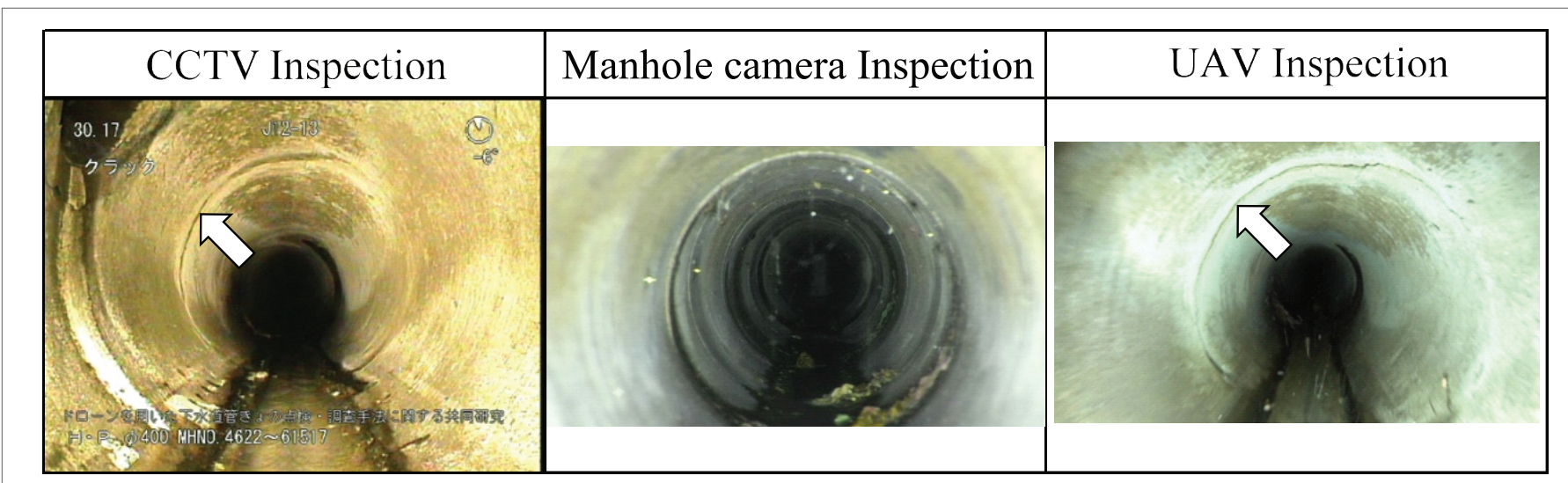

Figure 6: Crack obtained by each inspection method.

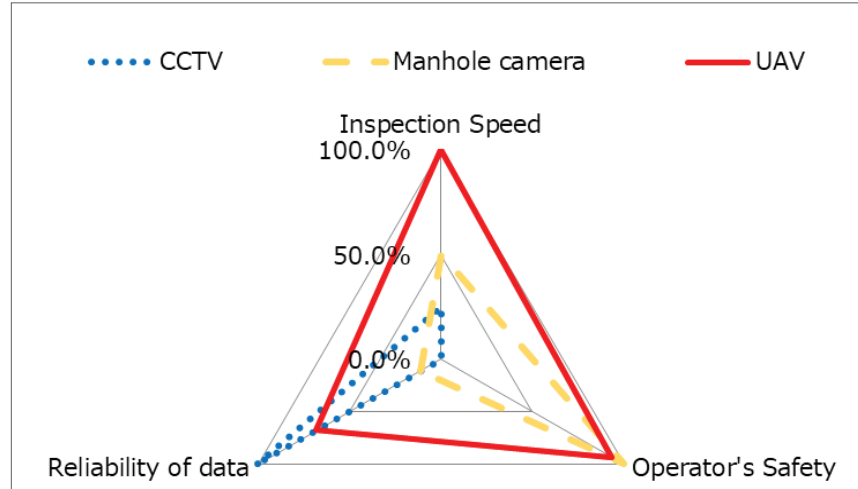

Figure 7: Result of comparison.

openings and number of inspections without the operator entering the manhole. The ratios were CCTV $=0 \%$, manhole camera $=100 \%$, and $\mathrm{UAV}=93.3 \%$. The one opening recorded for UAV had happened when the operator misguided the UAV to a deep gap and had to enter the manhole to retrieve it. This could have been prevented by examining the construction drawings prior to the inspection. Basically, an inspection by UAV was able to carry out the whole process from above ground, including preparation, inspection and clean up (Figures 4 and 5).

\section{Reliability of data}

The results of CCTV are shown in table 4 and the levels of severities (A-C) are explained in table 4 as A being the most serious level. The criteria shown in table 5 was taken from the "Guideline for sewer management" issued by Japan Sewerage Works Association (JSWA) $[4,9]$. A manhole camera was also used to inspect the same section and the result was compared to that of CCTV. The visibility (screen clarity) was evaluated by how many defects the method detected for each item (Figure 6). Figure 6 shows a crack image obtained by CCTV, UAV and a manhole camera.

The matching rate (of 9 items, excluding "Deformed in Vertical direction" and "Attached deposit, grease" which were not applicable in this section) to CCTV was $11 \%$ for manhole camera and $68 \%$ for UAV. Out of these results, the rate for critical defects (items 1-5) was $8 \%$ for manhole camera and $74 \%$ for UAV and for maintenance-related defects (items 6-9), 22\% and 44\%.

UAV matching results at $74 \%$ for critical defects which affect structural integrity can be considered as a high matching rate. Among the items, corrosion, displaced joints and extrusion of lateral pipes scored a $100 \%$ match to the result of CCTV inspection. This 
Table 5: Levels of severities $[4,9]$

\begin{tabular}{|c|c|c|c|c|c|}
\hline \multirow{5}{*}{ 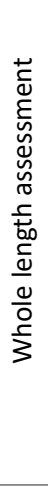 } & \multicolumn{2}{|l|}{$\begin{array}{l}\text { Levels } \\
\text { Sewer conditions }\end{array}$} & A & B & C \\
\hline & \multicolumn{2}{|l|}{ Corrosion of pipes } & $\begin{array}{l}\text { Steel reinforcement } \\
\text { visible }\end{array}$ & $\begin{array}{l}\text { Aggregate } \\
\text { visible }\end{array}$ & $\begin{array}{l}\text { Surface } \\
\text { roughness }\end{array}$ \\
\hline & \multirow[b]{3}{*}{$\begin{array}{l}\text { Deformed in Vertical } \\
\text { direction }\end{array}$} & $\begin{array}{l}\text { (inner diameter) less } \\
\text { than } 700 \mathrm{~mm}\end{array}$ & $\begin{array}{l}100 \% \text { or greater of inner } \\
\text { diameter }\end{array}$ & $\begin{array}{l}50 \% \text { or greater of inner } \\
\text { diameter }\end{array}$ & $\begin{array}{l}\text { less than } 50 \% \\
\text { of inner diameter }\end{array}$ \\
\hline & & $\begin{array}{l}\text { (inner Diameter) } \\
\text { between } 700 \mathrm{~mm} \text { and } \\
1,650 \mathrm{~mm}\end{array}$ & $\begin{array}{l}50 \% \text { or greater of inner } \\
\text { diameter }\end{array}$ & $\begin{array}{l}25 \% \text { or greater of inner } \\
\text { diameter }\end{array}$ & $\begin{array}{l}\text { less than } 25 \% \\
\text { of inner diameter }\end{array}$ \\
\hline & & $\begin{array}{l}\text { (inner diameter) } \\
\text { between 1,650 } \mathrm{mm} \text { and } \\
3,000 \mathrm{~mm}\end{array}$ & $\begin{array}{l}25 \% \text { or greater of inner } \\
\text { diameter }\end{array}$ & $\begin{array}{l}12.5 \% \text { or greater of inner } \\
\text { diameter }\end{array}$ & $\begin{array}{l}\text { less than } 12.5 \% \\
\text { of inner diameter }\end{array}$ \\
\hline \multirow{14}{*}{ 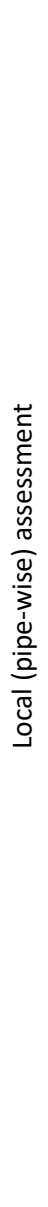 } & \multicolumn{2}{|l|}{$\begin{array}{l}\text { Levels } \\
\text { Sewer conditions }\end{array}$} & a & b & c \\
\hline & \multirow[b]{4}{*}{$\begin{array}{l}\text { Breakage/ longitudinal } \\
\text { crack }\end{array}$} & \multirow[b]{2}{*}{$\begin{array}{l}\text { Reinforced } \\
\text { concrete pipe, etc. }\end{array}$} & Collapsed & \multirow[b]{2}{*}{$\begin{array}{l}\text { Longitudinal crack } \\
2 \mathrm{~mm} \text { or greater in width }\end{array}$} & \multirow[b]{2}{*}{$\begin{array}{l}\text { Longitudinal crack } \\
\text { less than } 2 \mathrm{~mm} \text { in width }\end{array}$} \\
\hline & & & $\begin{array}{l}\text { Longitudinal crack } \\
5 \mathrm{~mm} \text { or greater in width }\end{array}$ & & \\
\hline & & \multirow[b]{2}{*}{ Clay pipe } & Collapsed & \multirow[b]{2}{*}{$\begin{array}{l}\text { Longitudinal crack } \\
\text { less than } 50 \% \\
\text { of pipe length }\end{array}$} & \multirow[b]{2}{*}{--} \\
\hline & & & $\begin{array}{l}\text { Longitudinal crack- } \\
50 \% \text { or greater of pipe } \\
\text { length }\end{array}$ & & \\
\hline & \multirow[b]{2}{*}{ Circumferential crack } & $\begin{array}{l}\text { Reinforced } \\
\text { concrete pipe (RC) } \\
\text { etc. }\end{array}$ & $\begin{array}{l}\text { Circumferential crack } \\
5 \mathrm{~mm} \text { or greater in width }\end{array}$ & $\begin{array}{l}\text { Circumferential crack } \\
2 \mathrm{~mm} \text { or greater in width }\end{array}$ & $\begin{array}{l}\text { Circumferential crack } \\
\text { less than } 2 \mathrm{~mm} \text { in width }\end{array}$ \\
\hline & & Vitrified clay pipe (VC) & $\begin{array}{l}\text { Circumferential crack } \\
\text { two-thirds or greater of } \\
\text { the circumferential length }\end{array}$ & $\begin{array}{l}\text { Circumferential crack } \\
\text { less than two-thirds of } \\
\text { circumferential length }\end{array}$ & -- \\
\hline & \multirow{2}{*}{\multicolumn{2}{|c|}{ Displaced joints }} & & $\begin{array}{l}\text { Reinforced concrete pipe } \\
\text { etc.: } 70 \mathrm{~mm} \text { or greater }\end{array}$ & $\begin{array}{l}\text { Reinforced concrete pipe etc.: less } \\
\text { than } 70 \mathrm{~mm}\end{array}$ \\
\hline & & & Extruded joints & $\begin{array}{l}\text { Vitrified clay pipe: } \\
50 \mathrm{~mm} \text { and over }\end{array}$ & $\begin{array}{l}\text { Vitrified clay pipe: } \\
\text { less than } 50 \mathrm{~mm}\end{array}$ \\
\hline & \multicolumn{2}{|l|}{ Infiltration } & Gushing & Running & Seeping \\
\hline & \multicolumn{2}{|l|}{ Extrusion of lateral } & $\begin{array}{l}50 \% \text { or greater of inner } \\
\text { diameter }\end{array}$ & $\begin{array}{l}10 \% \text { or greater of inner } \\
\text { diameter }\end{array}$ & $\begin{array}{l}\text { Less than } 10 \% \\
\text { of inner diameter }\end{array}$ \\
\hline & \multicolumn{2}{|l|}{ Attached deposit, grease } & $\begin{array}{l}\text { Blockage of } 50 \% \text { or } \\
\text { greater }\end{array}$ & $\begin{array}{l}\text { Blockage of less than } 50 \\
\% \text { of inner diameter }\end{array}$ & -- \\
\hline & \multicolumn{2}{|l|}{ Roots intrusion } & $\begin{array}{l}\text { Blockage of } 50 \% \text { or } \\
\text { greater }\end{array}$ & $\begin{array}{l}\text { Blockage of less than } 50 \\
\% \text { of inner diameter }\end{array}$ & -- \\
\hline & \multicolumn{2}{|c|}{ Attached deposit, mortar } & $\begin{array}{l}\text { Blockage of } 30 \% \text { or } \\
\text { greater }\end{array}$ & $\begin{array}{l}\text { Blockage of } 10 \% \text { or } \\
\text { greater }\end{array}$ & Blockage of less than $10 \%$ \\
\hline
\end{tabular}

score owes to the UAV's capability of being able to fly to the center of the sewer section, collect images from a close distance and detect defects, whereas a manhole camera could only collect images from a manhole. On the other hand, cracks, root intrusion and mortar deposit showed a matching rate of only $50 \%$ or less. The reasons for this low matching rate could be caused by the low visibility that UAV occasionally encounters- the downwards airflow generated by the UAV splashes the water and the water sticks to the lens. Or, the narrow viewing angle blurred the image and made it difficult for the operator to detect the defects. Therefore, camera selection will be an issue for future development. The result that lateral blockage showed as low as $0 \%$ matching came from the UAV not having a lateral vision. Without this capability, detecting lateral blockage was difficult.

It can be said that even though some items showed less accuracy to CCTV, the overall score was better than that of a manhole camera. Therefore, UAV can be seen as a possible screening method for pipe inspection [10]. 
Table 6: The number of defects detected by each inspection method.

\begin{tabular}{|c|c|c|c|c|c|c|c|}
\hline & \multirow{3}{*}{ Defects } & \multirow{3}{*}{ Rank } & \multirow{3}{*}{ CCTV [1] } & \multirow{3}{*}{$\begin{array}{c}\text { Manhole camera } \\
\text { [2] }\end{array}$} & \multirow{3}{*}{ UAV[3] } & Manhole camera & UAV \\
\hline & & & & & & Matching rate to & Matching rate to \\
\hline & & & & & & {$[2] \div[1]$} & {$[3] \div[1]$} \\
\hline \multirow{16}{*}{ 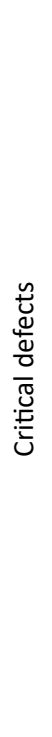 } & \multirow{3}{*}{ 1. Corrosion } & A & - & - & - & - & - \\
\hline & & B & 1 & 0 & 1 & $0 \%$ & $100 \%$ \\
\hline & & C & 2 & 0 & 2 & $0 \%$ & $100 \%$ \\
\hline & \multirow{3}{*}{ 2. Breakage } & a & 3 & 1 & 3 & $33 \%$ & $100 \%$ \\
\hline & & $\mathrm{b}$ & 8 & 2 & 8 & $25 \%$ & $100 \%$ \\
\hline & & c & 6 & 0 & 3 & $0 \%$ & $50 \%$ \\
\hline & \multirow{3}{*}{ 3. Cracks } & a & 1 & 0 & 0 & $0 \%$ & $0 \%$ \\
\hline & & $\mathrm{b}$ & 5 & 0 & 4 & $0 \%$ & $80 \%$ \\
\hline & & c & 8 & 0 & 3 & $0 \%$ & $38 \%$ \\
\hline & \multirow{3}{*}{ 4. Displaced joints } & a & - & - & - & - & - \\
\hline & & $\mathrm{b}$ & - & - & - & - & - \\
\hline & & c & 3 & 0 & 3 & $0 \%$ & $100 \%$ \\
\hline & \multirow{3}{*}{ 5. Infiltration } & a & - & - & - & - & - \\
\hline & & $\mathrm{b}$ & - & - & - & - & - \\
\hline & & c & 1 & 0 & 1 & $0 \%$ & $100 \%$ \\
\hline & Subtotal & $A(a)+B(b)+C(c)$ & 38 & 3 & 28 & $8 \%$ & $74 \%$ \\
\hline \multirow{13}{*}{ 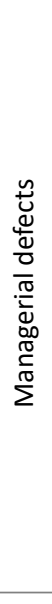 } & \multirow{3}{*}{$\begin{array}{l}\text { 6. Extrusion of } \\
\text { lateral pipes }\end{array}$} & a & - & - & - & - & - \\
\hline & & $\mathrm{b}$ & - & - & - & - & - \\
\hline & & c & 1 & 1 & 1 & $100 \%$ & $100 \%$ \\
\hline & \multirow{3}{*}{ 7. Root intrusion } & a & - & - & - & - & - \\
\hline & & $b$ & 3 & 0 & 1 & $0 \%$ & $33 \%$ \\
\hline & & c & - & - & - & - & - \\
\hline & \multirow{3}{*}{$\begin{array}{l}\text { 8. Attached } \\
\text { deposit (mortar) }\end{array}$} & a & - & - & - & - & - \\
\hline & & $b$ & - & - & - & - & - \\
\hline & & c & 4 & 1 & 2 & $25 \%$ & $50 \%$ \\
\hline & \multirow{3}{*}{$\begin{array}{l}\text { 9. Blockage of } \\
\text { lateral }\end{array}$} & a & - & - & - & - & - \\
\hline & & $\mathrm{b}$ & - & - & - & - & - \\
\hline & & c & 1 & 0 & 0 & $0 \%$ & $0 \%$ \\
\hline & Subtotal & & 9 & 2 & 4 & $22 \%$ & $44 \%$ \\
\hline & Total & & 47 & 5 & 32 & $11 \%$ & $68 \%$ \\
\hline
\end{tabular}

\section{Summary}

The results from the comparison can be summarized as the following.

- In regard to efficiency, UAV inspection was the most efficient as it took the least time to complete the inspection compared to CCTV and manhole camera, $1 / 4$ and $1 / 2$ respectively. The high efficiency was achieved for the UAV could inspect faster and inspect multiple paths in one operation.

- $\quad$ Safety was also found to be better. The entire UAV inspection from preparation, image collection to retrieval can be concluded from above the ground without the operator entering the manhole. This reduces the exposure to unsafe environment.
- Data reliability can be said to be similar or better when compared to manhole camera. The defect detection rate was $68 \%$ of CCTV whereas manhole camera was $11 \%$. The detection rate was similar or higher compared to manhole camera in each of the defect categories and ranks.

\section{Conclusion}

From the observed results, it can be concluded that UAV inspection can more efficiently and more safely find the area which require a more detailed inspection when compared to CCTV inspection. When compared to manhole camera as a screening method, UAV has similar or better defect detection rate as it can travel through the pipe. It can be said that UAV is an effective screening method to efficiently conduct CCTV inspection (Figure 7). 
Moving forward, optimization of the camera specification can help improve the image quality for a higher defect detection rate, and an overall operational ease of use improvement could allow a much faster inspection using UAV. UAV inspection has the potential to become a highly effective solution for sewer management (Table 6).

\section{References}

1. Ministry of Land, Infrastructure, Transport and Tourism (2018) Sewer Maintenance (in Japanese). Japan.

2. Japan Ministry of Land, Infrastructure, Transport and Tourism (2020) Nihon Suido Shimbun-sya Public sewage works guideline (in Japanese). ISBN978-4-93-0941-72-5, Japan.

3. Japan Sewage Works Association (2018) Sewer National database (in Japanese). Japan.

4. Japan Sewage Works Association (2014) Guideline of Sewage facility management (in Japanese). Japan.
5. Kenzo Nonami (2018) All about industrial application of drones (in Japanese). Ohmsha, Japan.

6. Ippei Yamashita (2018) Drone textbook Advanced text Unmanned aerial worker test (drone certification) Level 2 correspondence. Japan.

7. Japan Sewage Works Association (2016) Guideline of Sewer pipe facility stock management (in Japanese). Japan.

8. Japan Sewage Works Association (2020) Manual of Sewage facility management works cost estimate (in Japanese). Japan.

9. Japan Sewer Collection System Maintenance Association (2019) Manual of Sewer pipe management (in Japanese). Japan.

10. Yusuke Inagaki, Hiroshi Ikeda, Patrik Ken Takeuchi, Yoshihiko Yato, Takayuki Sawai (2020) An effective measure for evaluating sewer condition: UAV screening in comparison with CCTVs and manhole camera. Water Pract Technol 15: 482-488. 